\title{
The relationship between residential development land prices and house prices
}

\section{Article}

Accepted Version

Ball, M., Shepherd, E. and Wyatt, P. (2021) The relationship between residential development land prices and house prices. Town Planning Review. ISSN 1478-341X doi: https://doi.org/10.3828/tpr.2021.27 Available at https://centaur.reading.ac.uk/97135/

It is advisable to refer to the publisher's version if you intend to cite from the work. See Guidance on citing.

To link to this article DOI: http://dx.doi.org/10.3828/tpr.2021.27

Publisher: Liverpool University Press

All outputs in CentAUR are protected by Intellectual Property Rights law, including copyright law. Copyright and IPR is retained by the creators or other copyright holders. Terms and conditions for use of this material are defined in the End User Agreement.

\section{www.reading.ac.uk/centaur}

\section{CentAUR}

Central Archive at the University of Reading

Reading's research outputs online 


\title{
THE RELATIONSHIP BETWEEN RESIDENTIAL DEVELOPMENT LAND PRICES
}

\section{AND HOUSE PRICES}

\author{
Michael Ball \\ Edward Shepherd \\ Peter Wyatt
}

\section{KEYWORDS}

Residential land; land market; housing markets; development

\begin{abstract}
There exists apparent disagreement between two areas of literature regarding the relationship between house prices and land prices. In the professional literature it is argued that high house prices cause high residential development land prices. In some of the policy literature it is argued that it is land price increases that are behind increasing house prices. We argue that this is a rather artificial dichotomy and arises from two different ways of thinking about the relationship between land and house prices. To demonstrate this we explore how housing and residential land markets work and how their price responses are interrelated.
\end{abstract}




\section{INTRODUCTION}

Much ink has been spilled over the relationship between residential development land prices ${ }^{1}$ and house prices. At the core of this debate is the question of whether high house prices cause high residential development land prices or the other way around. It will be argued here that the one-way direction of causation implied in the debate is misconstrued because demand and supply factors influence house and land price and output outcomes simultaneously. The paper draws on existing academic and policy literature to present the underlying theories associated with basic postulates about development land markets and housing markets and how pricing within these two distinct, but interrelated, markets works.

In the current context of the 'housing crisis' in the UK it is important for policymakers to understand the nature of these market dynamics and how they work to produce house and land prices so that appropriate policies can be identified that seek to deliver sufficient housing at more affordable levels. Indeed, there is an extensive literature exploring potential policy options in this regard (e.g. Ball, 2010; Meen, 2011; Bentley, 2016, 2017; Griffiths \& Jeffreys, 2013; Macfarlane, 2017; Murphy, 2018; O’Brien, 2018; Shelter, 2016) and the government published a white paper in August 2020 which proposed reform in this policy area (MHCLG, 2020). In many of these papers, a key area for policy intervention is the development land market, where buyers compete for the land on which houses are to be built. This is for two obvious reasons: a) land is an essential component in the production of a dwelling, and b) the value of a dwelling is a composite of its attributes, including land and its location. It is clear, therefore, that the supply and price of housing is related to the supply and price of residential development land. It is the objective of this paper to clarify the nature of this relationship.

The paper starts by exploring the apparent disagreement that exists between some parts of the professional and policy literature regarding the relationship between land prices and house prices. The remainder of the paper examines the nature of this relationship. First, the paper explores how housing market dynamics interact to produce house prices. The characteristics of the residential development process are then summarised before the nature of the development land market is examined to explain how residential development land prices are determined. The paper concludes by showing how supply and demand dynamics within both the housing market and the residential development land market intersect to influence one another simultaneously. It is concluded, therefore, that there is not a single or one-way direction of causation between residential development land and housing markets. However, the following two statements can be made: 1) the housing market affects the land market (and land prices) rapidly; and 2) the land market affects house prices more slowly.

\footnotetext{
${ }^{1}$ By 'residential development land' we mean land that has the potential to be developed for a new or more intensive residential-led use and is therefore valued and transacted as such. In this paper, unless otherwise specified, 'land', 'residential land' and 'housing land' refer to 'residential development land' as here defined.
} 


\section{LAND PRICES AND HOUSE PRICES - CLARITY OR CONFUSION?}

The demand for residential land is a 'derived' demand as it is a necessary input to housebuilding. Therefore, unsurprisingly, the dominant view expressed in the professional or practitioner-focused literature regarding development land prices and house prices is that the price of residential development land is driven by the price of new homes (Hudson, 2015; Banks, 2017; Smith, 2017; Ward et al, 2018). This view corresponds with the 'residual' calculations that market professionals use, whereby development costs are subtracted from the total anticipated value of the new homes built on a site to arrive at a 'residual land value'. Therefore, it is argued that the higher the price it is anticipated the new homes can be sold for, the higher the price that can be paid for residential development land (assuming no change in other development costs such as construction or the amount of developer profit).

In contrast, some of the policy papers produced by think tanks and policy specialists present the relationship between house prices and land values in apparently different terms. They argue that it is the increasing price of land which has been 'driving' increasing house prices (e.g. Davis \& Palumbo, 2008; Knoll et al, 2014; Macfarlane, 2017; Murphy, 2018; Ryan-Collins et al, 2017, 8). The analyses within these sources point out that the price of a house can be conceived as comprising two components - the price of the land and the price of the structure and argue that it is primarily increases in the price of the land component that is behind increasing house prices.

For example, Macfarlane (2017, 3-4) infers an implied land value component of house prices by subtracting estimated construction costs from total house prices. He then shows how this land component of house prices has grown significantly in the UK since 1995 compared to a much more modest rise in build costs over the same period. The conclusion can be drawn that the "driving force behind rising house prices has therefore not been increasing building costs but increasing land prices", which is "consistent with international evidence that suggests that house price volatility is primarily driven by land values" (Macfarlane, 2017, 3). Ryan Collins et al $(2017,113)$ also state that: "The vast majority of...increases in housing wealth and house prices [in the UK] have come not from increases in building costs, which have remained relatively flat, but from increases in land prices". Similarly, Knoll et al $(2014,29)$ in their study of global house price growth over the period $1870-2012$ argue that "higher land prices, not construction costs, are responsible for the rise in house prices in the second half of the 20th century"2.

It may appear from this as though two competing arguments are being made regarding the direction of causation between high residential development land prices and high house prices. From one perspective (the 'professional view'), it seems as though high residential development land prices are driven by high house prices. From the other perspective (the 'policy literature view') it looks as though high house prices are driven by inflated land prices. This seeming puzzle raises serious problems if these apparently different conceptions lead

\footnotetext{
${ }^{2}$ This wording does not appear in a subsequent version of the paper, although the following sentence does: "[T] the late twentieth century surge in house prices was due to sharply rising land prices." (Knoll et al, 2017, 349)
} 
to different solutions to housing shortages and lack of affordability. For example, one perspective may lead to the conclusion that policy should be targeted at managing land prices to bring house prices under control whereas the other perspective may lead to the conclusion that the land market does not influence house prices so policy should not necessarily be targeted at improving its efficiency.

However, the remainder of this paper will seek to demonstrate that the apparent dichotomy described above is in fact a rather artificial one and arises from two different (but not necessarily opposing) ways of thinking about the relationship between residential land prices and house prices. To put it in a stylised way, the 'professional view' is focused on how residential development land is priced by professional valuers and housebuilders when it is purchased as an input into the residential development process at a particular moment in time; whereas the 'policy literature view' models the land value component of housing (both new and existing) in order to think about the relationship between how the residential development land market works (including factors influencing the supply and price of development land) and the supply and price of housing. Despite some loose and confusing language around rising land values 'driving' or being 'responsible for' rising house prices, the views expressed in the policy literature quoted above should not necessarily be taken as arguing that it is the high value of the land component of housing that is by itself directly 'causing' high house prices, but rather that the land component has over time comprised a larger and larger proportion of the total price of housing suggests a degree of tightness in the residential development land market which is contributing to high house prices.

We now examine the relationship between the supply and price of residential development land and the supply and price of housing in a way that acknowledges both of the perspectives summarised above. We begin by summarising how the housing market works, taking into account its demand and supply characteristics. We then examine the market for residential development land in the UK and explore how the price for land is determined. We conclude by discussing the relationship between the supply of residential development land and the supply of housing and how the price responses of both are interrelated.

\section{THE HOUSING MARKET}

The links between house and development land prices and between the two markets can be identified by starting with the housing market. Like other markets, the amount and price of housing is determined by the interaction of demand and supply.

The housing market comprises all the transactions of homes put up for sale, including existing homes as well as new ones and conversions. It is a well-informed marketplace where information is effortlessly available on thousands of properties and their attributes. Price differences are well known and properties can easily be compared using online sources and professional advice. House price indices are now quite sophisticated and aid views of market trends and prospects. So, as people buy, sell and rent homes, differences in locations and attributes are almost seamlessly priced into overall property values. This means that there is not a separate new 
homes market where prices are determined differently from those of existing homes, rather newness is an attribute of some of the properties traded and priced as such (Marsh \& Gibb, 2011).

Beyond the housing market of current transactions lies the whole of the nation's stock of housing and it is valued at current transaction prices in the market. Looking at Land Registry for England and Wales residential transactions data, as shown in Figure 1, the stock of private houses in England alone at 20 million (MHLG, 2020) is almost twenty times the scale of the average annual transactions registered with the Land Registry. Moreover, new homes are only a limited part of total transactions, representing between $10 \%$ and $20 \%$ of annual transactions over the 14 year period shown; with second hand sales volumes fluctuating notably more than new build (Figure 1). Generalising in terms of supply effects, new homes constitute much smaller additions to the overall stock itself than of actual market transactions in a year and, so, influence the scale of total housing supply in any country only gradually. Nonetheless, it is the demand and supply situation in that overall stock that drives the market and new build. Decisions to buy and sell are complex and moves are sticky and spread out over time in the face of changes in circumstances, but the current flow of transactions should be seen a gradual 'stock adjustment' process, moving towards an ever-changing 'equilibrium', and this must be taken into account when examining the influence of land supply on the housing market.

Figure 1: Residential transactions and private housebuilding, 2005/6-2018/9

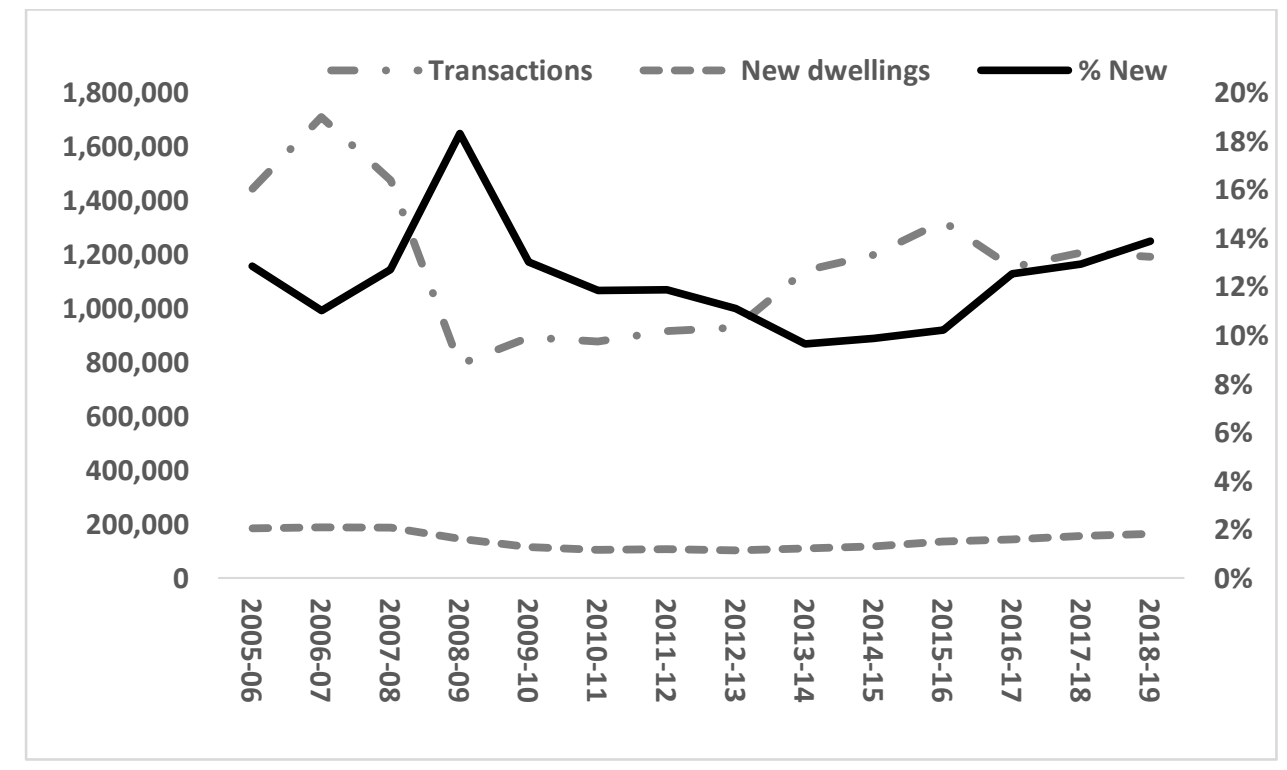

Note: Total \& new transactions of housing are shown as numbers on left axis; the share of new housing transacted, expressed as percentages of overall transactions of housing, on the right axis.

(Source: ONS, Land Registry) 


\section{Demand}

Housing demand identifies how much households are willing-to-pay ('can afford') for their home; the tenure choices they make about whether to rent or buy; and whether they are satisfied with their current accommodation or wish to move, given the prevailing array of house prices and rents. The demand for housing is affected by people's incomes and wealth. Better-off and more wealthy people tend to have better housing alongside higher consumption of many other goods. There is also a feedback element here, as housing forms an important part of household wealth. Individual housing demand choices are further influenced by the relative cost of housing, its 'affordability' versus other things you can do with your money, as well as the availability and cost of mortgage finance (Duca et al., 2010; Favara \& Imbs, 2015). Expectations play an important part too: will prices rise or fall; what will happen to interest rates, to household income and to other outgoings?

Furthermore, people need to have their homes connected to the other parts of their lives - jobs, leisure pursuits, family needs, etc. - so location matters. Prices vary locationally in terms of neighbourhood attractiveness and accessibility. Demand pressures are greatest in the largest and most economically successful towns and cities. Such preferences vary across age and income groups and for other reasons and they may change over time, as suggested in debates following the start of Covid19 pandemic. Central locations generally command premiums and more distant locations are generally cheaper; though prices vary considerably across neighbourhoods and with the available local attributes.

In this description of individuals' housing demand choices, prices come into play at three decision points:

1. whether to rent or buy;

2. the size/quality of the home, and;

3. its location.

These price influences have to be assessed in relation to what people want (their preferences) and their ability to pay (incomes, wealth and borrowing costs). The three decisions are made simultaneously by consumers and involve trade-offs, such as whether to live near the expensive centre or buy a bigger place further out and commute (Wong, 2002).

To examine housing demand as a whole, individual demands have to be aggregated, so levels and distributions of income and wealth matter, as do demographics although to a lesser extent. People are also mobile and may wish to move from one city or region to another, say, to find a better-paying job. However, the desirability of such moves will be influenced by the relative cost and availability of housing in both locations. Falls in housing costs, for example, may induce more inwards migration from other regions. Regional population flows consequently have to be included in the aggregate mix (Cameron \& Muellbauer, 1997; Leishman et al., 2008; Meen, 2011). 


\section{Supply}

The supply of houses comes from existing owners and from housebuilders. The decision to sell by existing property owners is influenced by their own housing demands, incomes and life choices at particular points in time, as well as relative house prices and the ease (or otherwise) of selling and moving.

Supply of new-build housing is driven by the cost of profitable supply. Housebuilders have to pay for construction, development land, finance and transactions items (legal and agency fees, planning, etc.) as well as award themselves what they regard to be a sufficient level of risk-weighted profit. Each of these elements influences how many new homes can be supplied at particular levels of house prices. Inputs have their own markets and developers have to bid enough in them to attract labour and land away from other uses. This means that in principle there is not an independent market for residential development land as land could in theory be developed for a range of uses (Evans, 2004). In practice, though, regulatory and other institutional constraints on land use and the resulting price differences across uses makes it clear to market participants which development sites might have the potential to be used for housing.

\section{Market outcomes}

The amount consumers decide to buy, and the amount suppliers decide to supply, depends on prevailing prices and there is a price where the two are equated. This is true of all functioning markets and housing is no different. In other words, supply and demand interact simultaneously. The economist, Alfred Marshall, over a hundred years ago, used a metaphor suggesting the roles of demand and supply in determining market prices are like the blades of a pair of scissors, both are required to produce the outcome (Marshall, 2013). The derived market clearing price is a moving target as the influences on demand and supply are continuously changing.

With housing, matters are complicated by having different tenures, existing and new properties, housebuilders and landowners, existing owners and first-time buyers and other categories of market player, the details of which vary from country to country (Ball, 2020). But although these different categories result in complex modelling of housing markets, in which land is a key input to new building, that should not confuse the essential nature of the relationship: house prices and residential development land prices are simultaneous outcomes of the interactions of buyers and sellers in their respective markets (Bramley, 2013; Ball et al., 2010).

If house prices are falling, this may be due either to collapsing demand or excessive supply. Observing the dynamics is useful in these contexts and it is relatively easy to answer simple questions like "has a sudden surge in supply been observed?' or 'have buyers deserted the market?' and consider appropriate policy responses from the resultant understandings. Conclusions on which side of the market is 'short', either demand or supply, points policymakers and their advisors to the appropriate direction of either stimulating demand or focusing on dealing with a supply glut.

Often causality may be complex but appropriate policy relevant questions can still be answered. Take the situation where nothing else changes but the demand for housing rises because falling interest rates have made 
borrowing cheaper. House prices will increase as a result. Should policymakers worry about the apparent lack of supply? That depends on for how long interest rates are expected to be low. If the fall is expected to be sustained, policy preferences might err towards encouraging more supply in order to allow people to realise their housing aspirations because of this fortuitous change in financial markets. Whereas, if interest rates are expected to rise again, policymakers may need to think about how to avoid potential problems resulting from destabilising mortgage debts or supply overbuilds induced by the resultant temporary rise in house prices (Miles \& Monro, 2019).

Housing markets and interest rates are of continuing contemporary importance because it has been argued that house price rises have been caused by income changes and interest rate falls rather than attributable to residential land shortages (Oxford Economics, 2016). However, while rising household earnings and falling interest rates have played a part in rising house prices, it is also the case that a key constraint on many people's housing aspirations is a tight supply of residential development land in locations where there is high demand for housing (Cavalleri et al. 2019). The resultant price rises choke off demand and enrich existing property and landowners. They make homeownership unaffordable for many and inter-regional moves challenging. Price rises also make it difficult for many young adults and others to set up an independent home. Interest rates and land shortage explanations in this context cannot be separated out as independent causes. Each affects one or other of the blades of the market 'scissors' and in doing so, distribute the welfare effects of the long-run interest rate improvement towards or away from housing consumers and property owners.

\section{THE HOUSING DEVELOPMENT AND RESIDENTIAL DEVELOPMENT LAND MARKET}

It is worth now summarising the housing development process and the place of land within it because it is through this that new housing supply is created. ${ }^{3}$ This process can a include a number of key elements:

1. Land acquisition: housing development land is identified and purchased from (or an agreement entered into with) the landowner/promoter by the housebuilder.

2. Feasibility: the housebuilder conducts ongoing feasibility work to identify a development that is both viable and deliverable. Viability monitoring continues throughout the process.

3. Permissions: the housebuilder secures the necessary permissions, including planning permission, currently subject to the agreed developer contributions and planning obligations.

4. Construction: once planning permission is granted, the housebuilder secures building inputs and the site is built out.

\footnotetext{
${ }^{3}$ It is important to note that this process is not always sequential, and the order of events presented here may alter. For example, land might be acquired before planning permission is sought. On the face of it, this might seem very risky, and it is certainly riskier than buying land with the relevant planning permission. However, land without planning permission would be cheaper and therefore presents an opportunity to make a larger profit if the risks turn out favourably for the developer.
} 
5. Marketing and sale: throughout the construction process, the new homes are marketed and sold offplan and/or following completion.

This process has a number of important characteristics:

1. The housing development process in the UK as in all market economies is dominated by private $\underline{\text { housebuilders }}$ and it is speculative, in the sense that is for the general market rather than a known buyer.

2. Development takes a long time, which means that housebuilders must wait a long time for their return, and this adds to the uncertainty associated with that return. Consequently, compared to alternative investment activities, developers require higher profit margins to compensate for the time and risk.

3. Development is costly and therefore usually requires borrowing. This adds to uncertainty and risk of the developer's equity investment due to the leverage effect of the debt, and the higher the debt, the higher the risk.

4. Construction costs will be influenced by choices of construction methods - which are in turn influenced by the available technologies and input costs. The availability of capital is affected by the finance market and the terms on which lenders are prepared to fund housing construction; while the prices and availabilities of labour and materials are driven by the level of housing construction activity, supply costs and availabilities, and skills mixes.

5. Most inputs into the development process are purchased in competitive markets, but the supply of residential development land is somewhat different because its market is regulated by the planning system, making land a rare commodity where each item's use has to be approved by government. Moreover, landowners can choose whether and when to release land for development and their decisions will often be influenced by longer time horizons and broader considerations than is the case for many other inputs. Landowner behaviour is therefore recognised as a being an important factor in the supply of development land and site assembly. Landowners may be 'active' or 'passive' with varying degrees of knowledge and interest in development and varying strategies for its release based on expectations regarding future market and fiscal conditions (Adams \& May, 1991; Adams et al, 2000; Adams et al, 2001; Goodchild \& Munton, 1985; Holtslag-Broekhof et al, 2014).

When housebuilders bid for land, they are competing with competitor housebuilders and with others interested in non-housing land uses. Housebuilders' obvious strategies are to look at a variety of sites in terms of the prices at which landowners are willing to sell and the relative profitability of building there rather than elsewhere. Therefore, the residential development land market is like any other in that the interaction between the demands of many potential users and the supply offers of many suppliers determines prevailing prices. Put another way, for land to join the housing supply pipeline housebuilders have to outbid other potential uses and their bids will be influenced by the prices at which they anticipate they can sell new homes (Evans, 2004). The outcomes will be locationally-driven relative differences in prices and will also reflect a general prevailing 'price level' for land within any specific, city, region or country. 


\section{Land monopolies}

Land differs from markets where more standardised goods are sold, because it is heterogeneous: no site is exactly like another. Land is locationally fixed and sites vary widely in usefulness and attractiveness. This locationally-bound nature means each landowner has a degree of monopoly power. More generally, if the supply of land for particular uses faces restrictions, its price will rise relative to other uses. Such use constraints may result from planning regulations which seek to limit urban expansion by controlling the transfer of agricultural land to urban uses. A reluctance of rural landowners to sell land for development due to adverse tax factors would have similar effects.

However, monopoly power generally has limitations. An individual private landowner or developer is unlikely to control the whole of a locality's land supply. If they hold off, others will be encouraged to sell. Consequently, it is unsurprising that studies of private land monopolies rarely find credible evidence of an impact on market prices of monopoly power (OFT, 2008; Letwin, 2018). Furthermore, if such actions did exist and persisted, housebuilding is likely to shift elsewhere to the long-term detriment of the local economy and, with it, the landowner/developer monopolist's land values (Glaeser \& Gyourko, 2018).

Nevertheless, monopoly power is likely to be more pervasive if it is state-run or sanctioned, because it is then much harder to avoid. This can occur with planning controls. If local land-use policies consistently limit land release across an area to lower than market clearing levels, land prices will rise. Potentially, the regional effect could be widespread if many local authorities adopt similar planning strategies and central government acquiesces (Barker, 2004; Hilber \& Vermeulen, 2016; Cheshire et al., 2014). Such land allocation policies may also inadvertently strengthen private landowner/developers' monopoly power when land is allocated for release via plans which require new local development to take place on their sites and not elsewhere. However, such market effects must be traded off against the benefits afforded by planning, including those deriving from its role in managing the negative externalities of new development and in providing a forum where the "public interest' (however defined) can be considered in the mediation of competing demands for the use and development of land.

\section{How substitutable is land?}

Another important distinction between the residential land market and the housing market relates to substitutability. Generally, two similar houses in a locality are more substitutable for one another than two equivalent pieces of development land. This is because houses are typically closer substitutes. There are many similar ones and they are traded in large volumes, so price comparisons are relatively straightforward. In contrast, development sites vary widely in terms of their development potential, planning requirements, site preparation, etc. and are traded far less often than dwellings. Even when bought, the exact form of any future land development may remain uncertain. These factors are reflected in the frequent marked differences in development land prices in specific localities. Imperfect substitutability means it is also difficult to use standard 'comparison' valuation methods (Crosby et al, 2013,6), so valuers struggle when trying to value sites using 
estimates of land values derived from the 'land residual' element of local house prices. This inevitably encourages disputes over the level of developer contributions that local authorities require.

\section{LAND PRICE DETERMINATION}

Although the price of a house can be conceived hypothetically as comprising the sum of its land and structure components (as has been argued in the 'policy literature view' discussed earlier), house purchasers are unlikely to think about the price of a home in that way. In the purchasers' eye, a house is a single entity - comprising a bundle of more or less desirable characteristics - and it is valued, priced and transacted as such. Nevertheless, statistically speaking, breaking a home into component prices is possible by applying an 'hedonic price' model that recognises that houses contain many attributes and house prices are a sum of the values of those attributes (Hill, 2011). Hedonic models are used to derive measures of house price inflation and to estimate component prices, like good quality schools, as measured by their contribution to local house values (Eurostat, 2013, Sirmans, et al., 2006). Many of the estimated components have land related elements, like property location, building and garden sizes, for example, but are still not reflecting the land market itself. This can be seen, for instance, in the fact that the relationship of component quantities to house prices might be non-linear - that is a $10 \mathrm{~m}^{2}$ garden may proportionally be valued more highly than a $50 \mathrm{~m}^{2}$ one, for example. Such differences may influence the mixes of properties in developer schemes when they assess bids for land, but do not proxy traded prices in the residential land development market itself.

The hedonic approach demonstrates what users value in housing and what they have to pay for specific characteristics in the marketplace, be they location, internal amenities or neighbourhood features. Housebuilders will be aware of this information when they formulate their schemes and on that basis estimate what they are willing to bid for land (see below). Note the direction of causality: house prices built up from property features affect housebuilders' willingness to pay for land. In the land market, residential developers will then have to compete against other potential uses for the land and will be unwilling to outbid them when it is unprofitable to do so. This competition for land will then feed back into the supply of housing and affect its price. It is the competition between potential users of land (offices, retail, residential, etc.) that is important here and provides an understanding of the distribution of land uses and prices between and across urban areas (Bruekner, 2011).

An hedonic model prices the components of existing property uses. However, all land has the potential to be 'developed' into a new use. As the change would take place in the future and may never occur, the precise value of the most financially attractive new use cannot be fully known. Instead, practices have grown up to estimate the 'best' (i.e. the one that outbids all others) 'new use' and consequently the associated value of the land in that use (Wyatt, 2013). That sum is often referred to as the development value of the land. The estimation of this alternative view of land price is generally undertaken using a 'residual price model' that divides house prices into forecast building costs and implicit land values. Therefore, in this formulation the land component of any home has intrinsic, though possibly entirely notional, development value. This estimate will influence bids when 
a purchase is made in order to demolish. However, this would not be a purchase of the land component of an existing house, but rather a purchase of development land with a demolition component factored in.

Housebuilders are widely known to use the residual approach when formulating bids for residential development land (Wyatt, 2013). They will estimate how much they can pay for land, given anticipated house prices, construction costs, finance costs, transactions costs and regulatory costs (cost of applying for planning permission and the share of the site that has to be allocated to government uses via developer contributions). This method can be stated simply in the following equation:

(1) Anticipated value of the completed development

less

(2) The anticipated cost of delivery including housebuilder's profit

equals

(3) Housing development land price

The value and cost components of (1) and (2) are usually estimated by reference to comparable evidence from recent, similar developments. Anticipated completed development values are estimated from recent sale prices of similar houses in the locality and housebuilders' profit margins are usually assumed to be a target percentage of the value of the completed development. Delivery costs, net of land costs, are treated in similar ways, including construction and planning obligations costs.

Usually, land prices and housebuilder's profits are relatively smaller sums compared to the final value of the completed development and its delivery cost. This makes them volatile, because small shifts in total development value or delivery costs can lead to relatively large fluctuations in land price bids and housebuilders' profits. This means that housebuilders can make significantly higher than expected levels of profit if the value created by the development turns out to be more than anticipated when the land was purchased, or if delivery costs are unexpectedly lower. Conversely, they can make significantly lower profits if development leads to weaker sales values (or costs more to deliver) than anticipated when the land was purchased. Such volatility is exacerbated by the extended timeframes of residential development. It takes a long time, stretching frequently to years or even decades, to develop large sites. The capital sums invested and borrowed are usually substantial, with negative cash flows for lengthy initial periods and final outcomes unknown for long periods of time. During the development phase, economic recessions, financial crises and other more modest events may adversely affect the 'anticipated' elements in the residual calculation. Such downside risks and long-term uncertainty are additional factors that housebuilders believe they require compensation for in the form of relatively high target profit levels.

The residual method is a way of showing that housebuilders behave rationally when bidding for land. If the residual calculation is unattractive or other more profitable opportunities exist, then the bid will not proceed. 
Even if it does, there is no guarantee that it will win out in competition with other bids. Furthermore, external attempts to nail down 'land value uplift' and 'developers' returns' are exercises fraught with difficulty even with successful bids, because of the importance of risk factors and assumption-related considerations in bid prices.

Therefore, while there may be occasions when housebuilders make optimistic assumptions about the value of a completed development or its delivery cost to outbid competitors, over-optimism is unlikely to predominate in land price determination. Of course, developers are likely to have differing views at any point in time regarding future market conditions, leading to a scatter of bids around a mean market expectation. Yet optimists have to find someone to fund their optimism and lenders are likely to be wary. Furthermore, those that embark on such development are more likely to come to grief than wiser buyers. Nonetheless, there can be times when a 'herd' behaviour of over-priced bids creates a price 'bubble', which will subsequently subside in a market crisis; though such events tend to be relatively short-lived (Ball, 2006).

Developers may pay seemingly high prices for land if they spot regulatory or policy weaknesses and seek to game the system. Housebuilders might lower their estimates of the costs of planning obligations when submitting their bids in the hope that they can negotiate with the local authority to reduce them after the land has been acquired (Sayce et al, 2017). This practice is believed to have occurred in London and the south of England in the 2010's in relation to affordable housing, due to housebuilders and landowners exploiting weakly drafted English planning policy (Crosby et al, 2013; Crosby \& Wyatt, 2016). The relevant National Planning Policy Guidance on viability was redrafted in 2018 in an attempt to address this problem (MHCLG, 2018).

Land price is not simply a function of how much to pay to bid the land away from its existing use, but also how much to pay to bid the land away from other potential competing uses, as noted earlier. Therefore, although the 'land as residual' pricing method is understandably widely accepted, it cannot reasonably be extended to the overall land market because the market pricing mechanisms involve intense, pro-active bidding for land by purchasers in competition with other bidders and potential uses. This process includes inducing landowners themselves to sell, as they will have their own reservation prices below which they will continue to hold onto the land.

It is important to emphasise that a residual calculation is simply a method for pricing development land which may produce various results depending on people's expectations. When land is sold, all bidders may use the residual approach when formulating their bids, but only one bid wins. The actual price (or value) of development land is simply that which is eventually agreed between the buyer and the seller in a competitive market. Thus, the residual method for pricing land is purely a pricing model, into which bidders plug their own assumptions and expectations regarding market conditions; whereas the actual price of development land is what has been paid to bid land away from other bidders/uses. However, it is worth re-emphasising that a key determinant of land price in the residual pricing model is how much the bidder anticipates the completed homes can be sold for. Therefore, in the residual model, housing land prices are driven in large part by existing house prices, although filtered through the mechanisms and asset characteristics discussed above. 
HOUSING LAND SUPPLY, HOUSING SUPPLY AND PRICE RESPONSES

So far, the housing market demand and supply dynamics have been explored as well as how residential development land prices are determined. Now, the interaction of the two markets will be examined further.

Housebuilders build more homes as demand rises and need more land to do so. The development pipeline is long, so the fruits of a building upturn will only come on to the housing market at an often-prolonged later date. Developers in the short term can speed up completions on existing sites. However, in the main, development on them will be programmed in a steady fashion on account of production needs and potential market absorption of the new homes. Progress may unfortunately be punctuated by shocks and gradual recoveries from them, such as during the $2007 / 8$ Global Financial Crisis and the Covid-19 pandemic. Therefore, most increases in housing demand in the short run have to be absorbed by variations in supply from the existing stock, putting upwards pressure on prices to induce more existing owners to sell and to dampen down demand. So, demand increases in the housing market will affect both house prices and the demand for residential land and push up land prices swiftly. Conversely, a falling housing market leads to a rapid drop in transactions and declining prices in both markets. Therefore, price transmission from the housing to the land market is fast.

By contrast, this is not the case in the reverse direction from the residential development land market to the housing market. Rates of change in housebuilding are asymmetrical, generally being more flexible in a downwards direction than upwards in the short-term. This is because site developments can be suddenly halted in market crashes, whereas the aforementioned long housing development lags mean that increases in output are slow to materialise.

In downturns when demand melts away, housebuilders have little option but to sharply cut back on production and land purchase. Builders, particularly those facing bankruptcy, will additionally be encouraged to reduce or even cease activity by creditors fearing covenant breaches and loss of loans. Occasionally lenders may irrationally continue to extend loans in the hope that builders' market problems will go away. This occurred in some countries, such as Spain and Ireland, at the time of the 2007/8 Global Financial Crisis, exacerbating supply overhangs that prolonged downswings there (Bardhan et al., 2011). These supply responses to downswings generate persistence effects, not simply in terms of prolonged excess supply but also in terms of ruptured land procurement and associated regulation processes.

In upswings, labour shortages may constrain building and policy changes to facilitate more development may be slow to evolve. Planning policy can take years to come to fruition; then it can take further years to construct and deliver new houses (Barker, 2004; Ball, 2011). Consequently, the release of more residential development land can take a long time to feed through to an increase in housing supply. Moreover, as already noted, the overall scale of new building relative to the size of the housing market as a whole is relatively small except in a few localised areas of intense new build. 
It has been suggested that smoothed upward new-build rates are an indication that builders are manipulating markets through strategic behaviour: that they deliberately hold back output and thwart policies to expand housing supply more rapidly as that would mean lower sales prices and profits for themselves (House of Lords, 2016). Letwin (2018) notes that housebuilders only build out their development sites at the rate at which new homes can be absorbed into the local market without negatively affecting prices. Adams et al. (2009) argue that prices (net of incentives) fluctuate less than build rates. However, this interpretation needs some nuance because it does not follow through the implications of the implied alternatives.

Typically, existing homes represent most of the purchase options for buyers, so the prices of existing and new homes 'constrain each other' (OFT, 2008). On the supply-side, builders are restricted by the flow of inputs and neither land nor skilled labour supplies can be increased rapidly. Any major attempt to speed up activity can lead to marked escalations in input prices and declines in build quality (although the rate of build out on existing sites could be increased or decreased to a limited extent without these effects) (OFT, 2008).

All this means that any increase in any extra supply (and any consequent decrease in the price) of residential development land affects house prices slowly. This is because it is harder for residential developers to significantly ramp up delivery than it is for them to slow it down when market conditions change, so any increase in the supply of residential development land would take a long time to feed through to new housing delivery on that land. Furthermore, the increase in new housing via the increased supply of development land would have to be very significant to have any appreciable impact on the price of housing due to the fact that new housing comprises a small proportion of overall housing supply (Bramley, 1993; NHPAU, 2007; Meen, 2011). What these interrelationships demonstrate is that there is not a single or one-way direction of causation between residential development land and housing markets. Changes in house prices impact the price of residential development land quickly while changes in the supply (and price) of residential development land impact the supply (and price) of housing slowly.

\section{CONCLUSION}

The housing market and the residential development land market are distinct but related markets. The housing market comprises the whole stock: existing and new homes. Demand for houses is affected by income, wealth, cost of houses, availability of finance and expectations about the future. It varies from place to place because attractiveness and accessibility are key drivers. The supply of houses comes from existing homeowners and from housebuilders. The amount of new homes supplied, including their type and location, depends on their profitability which is determined by input costs and selling prices. Selling prices are determined by the current relationship between supply and demand for housing, including buyers' and sellers' views of future market conditions.

Residential development land is a key input into the supply of new housing. Housebuilders compete to secure sites from landowners and supply is regulated by the planning system. Housebuilders generally use the residual 
method for determining the bid for land; this is dependent on assumptions about the future cost and value of the proposed development and so bids may differ depending on bidders' expectations. However, there can only be one successful bid, and this sets the price.

There is not a single or one-way direction of causation between residential development land and housing markets, because demand and supply factors influence price and output outcomes simultaneously. However, returning to the apparent positions of the 'professional view' and the 'policy literature view' regarding these relationships explored earlier in the paper, the following two statements can be made: 1) the housing market affects the land market rapidly; and 2) the land market affects house prices more slowly. Changes in the demand for houses alter house prices as market activity picks up or slows down. Housing development land prices adjust swiftly to housing market price signals, encouraging or dampening the incentive to supply development land. Although changes in housing development land supply may alter land prices quickly, the influence on house prices will be attenuated and far slower.

High UK house prices indicate that a shortage of residential development land is a key factor alongside other factors such as household earnings and interest rates. But any policy that seeks to reduce residential development land prices by increasing supply in a competitive environment would reduce house prices only over the long-term. For example, planning reforms which have recently been proposed via the UK government's August 2020 white paper seem targeted at introducing a zoning system with the intention of creating the conditions for more land to be released for housing development. However, any such reforms would need to be conceived of as a long-term strategy and would (paradoxically) need careful planning with clear spatial and social objectives beyond the simple desire to deliver more homes. Such a strategy would also be beset by housing market fluctuations and complexities. Political ambitions for quick fixes in the context of changing market conditions - such as attempts to stimulate demand through first-time buyer discounts, direct state subsidies and transaction tax adjustments - are likely to have inflationary effects on housing and land prices and thereby worsen affordability. Moreover, any increase in land supply has to be sufficient to absorb long-term increases in housing demand caused by rising living standards, inter- and intra-regional migration, changing demography, and the resulting stimulus to demand generated by the more plentiful housing supply itself. This would alter the present distribution of the housing stock and relative house prices across the UK. Good spatially-informed planning would therefore be essential.

Acknowledgements: This article derives from a research paper commissioned by the Scottish Land Commission: Residential Development Land Prices and House Prices: A Discussion Paper (2020). The authors would like to thank the anonymous reviewers for their helpful comments. Any omissions or errors remain the responsibility of the authors. 


\section{REFERENCES}

ADAMS, D., DISBERRY, A., HUTCHINSON, N., and MUNJOMA, T. (2000), Mind the gap! Taxes, subsidies and the behaviour of brownfield owners, Land Use Policy, 17, 135-145.

ADAMS, D., DISBERRY, A., HUTCHINSON, N., and MUNJOMA, T. (2001), 'Urban redevelopment: contextual influences and landowner behaviour', Journal of Property Research, 18, 217-234.

ADAMS, D., LEISHMAN, C., and MOORE, C. (2009), 'Why not build faster? Explaining the speed at which British house-builders develop new homes for owner-occupation', Town Planning Review, 80, 291-314.

ADAMS, D., and MAY, H. (1991). 'Active and passive behaviour in land ownership', Urban Studies, 28, 687-705.

BALL, M. (2006), Market and institutions in real estate and construction, Blackwell, Oxford.

BALL, M. (2010), The housebuilding industry. Promoting recovery in housing supply, DCLG, London.

BALL, M. (2011), 'UK planning controls and the market responsiveness of housing supply', Urban Studies, 48, 349-362.

BALL, M. (2020) 'Classifying housing regimes. Is it worth doing? What are the alternatives?' Critical Housing Analysis, 7, 36-48.

BALL, M., MEEN, G., and NYGAARD, C.A.B. (2010), 'Housing supply revisited: Evidence from international, national, local and company data', Journal of Housing Economics, 19, 255-268.

BANKS, C. (2017), Time to look again at viability? Shelter Blog, 3 February 2017, https://blog.shelter.org.uk/2017/02/time-to-look-again-at-viability/ (accessed 9 October 2020).

BARDHAN, A., EDELSTEIN, R. H., and KROLL, C. A. (2011), Global housing markets: Crises, policies, and institutions, Wiley, Chichester.

BARKER, K. (2004), Review of housing hupply. Final report, HM Treasury, London.

BENTLEY, D. (2016), The housing question: overcoming the shortage of homes (report), Civitas, March 2016, https://www.civitas.org.uk/content/files/thehousingquestion.pdf (accessed 9 October 2020).

BENTLEY, D. (2017), The land question: fixing the dysfunction at the root of the housing crisis (report), Civitas, December 2017, https://www.civitas.org.uk/content/files/thelandquestion.pdf (accessed 9 October 2020).

BRAMLEY, G. (1993), 'Land-use planning and the housing market in Britain: the impact on housebuilding and house prices', Environment and Planning A, 25, 1021 - 1051.

BRAMLEY, G. (2013), 'Housing market models and planning', The Town Planning Review, 84, 9-35. 
BRUEKNER, J. (2011), Lectures on urban economics, The MIT Press, Cambridge, MA.

CAMERON, G., and MUELLBAUER, J. (1997), 'The housing market and regional commuting and migration choices', Scottish Journal of Political Economy, 45, 420- 446.

CAVALLERI, M., COURNÈDE, B., and OZSOGUT, E. (2019), 'How responsive are housing markets in the OECD? National level estimates', OECD Economics Department Working Papers, No. 1589, OECD Publishing, Paris, https://doi.org/10.1787/4777e29a-en (accessed 3 February 2021).

CHESHIRE, P. C., NATHAN, M., and OVERMAN, H. G. (2014), Urban Economics and Urban Policy: Challenging Conventional Policy Wisdom, Cheltenham, Edward Elgar.

CROSBY, N. and WYATT, P. (2016), 'Financial viability appraisals for site-specific planning decisions in England', Environment and Planning C: Government and Policy, 34, 1716 - 1733.

CROSBY, N., MCALLISTER, P. and WYATT, P. (2013), 'Fit for planning? An evaluation of the application of development viability appraisal models in the UK planning system', Environment and Planning B: Planning and Design, 40, 3-22.

DAVIS, M. and PALUMBO, M. (2008), 'The price of residential land in large US cities', Journal of Urban Economics, 63, 352-384.

DUCA, J., MUELLBAUER, J., and MURPHY, A. (2010), 'Housing markets and the financial crisis of 2007-2009: Lessons for the future', Journal of Financial Stability, 6, 203-217.

EUROSTAT (2013). Handbook on Residential Property Prices Indices (RPPIs), Eurostat, European Union, International Labor Organization, International Monetary Fund, Organisation for Economic Co-operation and Development, United Nations Economic Commission for Europe, The World Bank 2013. Luxembourg, European Union.

EVANS, A. (2004), Economics, real estate and the supply of land, Wiley, Chichester.

FAVARA, G., and IMBS, J. (2015), 'Credit supply and the price of housing', The American Economic Review, 105, 958-992.

GLAESER, E. and GYOURKO, J. (2018), 'The economic implications of housing supply', Journal of Economic Perspectives, 32, 3-30.

GOODCHILD, R. N., and MUNTON, R. (1985), Development and the landowner, Allen Unwin, London.

GRIFFITHS, M. and JEFFERYS, P. (2013), Solutions for the housing shortage: how to build the 250,000 homes we need each year (report), Shelter, July 2013.

https://england.shelter.org.uk/ data/assets/pdf file/0011/689447/Solutions for the housing shortage FINAL.pdf (accessed 9 October 2020). 
HILBER, C. and VERMEULEN, W. (2016), 'The impact of supply constraints on house prices in England', Economic Journal, 126, 358-405.

HILL, R. (2011), Hedonic Price Indexes for Housing (OECD Statistics Working Papers), 2011/01, OECD Publishing, Paris.

HOLTSLAG-BROEKHOF, S.M., BEUNEN, R., van MARWIJK, R., and WISKERKE, J.S.C. (2014) '“Let's try to get the best out of it" understanding land transactions during land use change', Land Use Policy, 41, 561-570.

HOUSE OF LORDS (2016), Building More Homes, (Select Committee on Economic Affairs 1st Report of Session 2016-17), House of Lords, London.

HUDSON, N. (2015), The value of land: a leveraged bet on house prices? (Savills Residential Research Housing Market Note), June 2015, https://www.savills.co.uk/research_articles/229130/188996-0 (accessed 9 October 2020).

KNOLL, K., SCHULARIK, M. and STEGER, T. (2014), No price like home: global house prices, 1870 - 2012, (CEPR Discussion Paper No. DP10166), September 2014. https://ssrn.com/abstract=2503396 (accessed 9 October 2020).

KNOLL, K., SCHULARIK, M. and STEGER, T. (2017), 'No Price Like Home: global House Prices, 1870-2012', American Economic Review, 107, 331-53.

LEISHMAN C., GIBB, K., MEEN, G., O'SULLIVAN, A., YOUNG, G., CHEN, Y., ORR, A. M., and WRIGHT, R. (2008), Scottish model of housing supply and affordability: Final report, Scottish Government, Edinburgh.

LETWIN, O. (2018), Independent review of build out rates: draft analysis. Ministry of Housing, Communities and Local Government, https://www.gov.uk/government/publications/independent-review-of-build-out-draftanalysis (accessed 9 October 2020).

MARSHALL, A. (2013), Principles of Economics. Palgrave edition, Palgrave Macmillan, London.

MACFARLANE, L. (2017), The housing land market in Scotland, (discussion paper), Scottish Land Commission, December 2017, https://landcommission.gov.scot/downloads/5de1a716b632b Land-Lines-Discussion-PaperHousing-Land-Market-Dec-2017.pdf (accessed 9 October 2020).

MARSH, A., and GIBB, K. (2011), Housing economics, Sage, London.

MEEN, G. (2011), 'A longrun model of housing affordability', Housing Studies, 26, 1081- 1103.

MHCLG (MINISTRY OF HOUSING, COMMUNITIES AND LOCAL GOVERNMENT) (2018), Viability. National Planning Practice Guidance, 24 July 2018. Ministry of Housing, Communities and Local Government, https://www.gov.uk/guidance/viability (accessed 9 October 2020). 
MHCLG (MINISTRY OF HOUSING, COMMUNITIES AND LOCAL GOVERNMENT) (2020), Planning for the future: White paper, August 2020, https://www.gov.uk/government/consultations/planning-for-the-future (accessed 9 October 2020).

MHCLG (MINISTRY OF HOUSING, COMMUNITIES AND LOCAL GOVERNMENT) (2020), Dwelling stock estimates: 31 March 2019, 21 May 2020, https://www.gov.uk/government/statistics/dwelling-stock-estimates-inengland-2019 (accessed 9 October 2020).

MILES, D. and MONRO, V. (2019), UK house prices and three decades of decline in the risk-free real interest rate, (Bank of England Staff Working Paper No. 837), London, Bank of England, https://www.bankofengland.co.uk/working-paper/2019/uk-house-prices-and-three-decades-of-decline-in-therisk-free-real-interest-rate (accessed 9 October 2020).

MURPHY, L. (2018), The invisible land: the hidden force driving the UK's unequal economy and broken housing market, (IPPR Commission on Economic Justice Discussion Paper), August 2018, https://www.ippr.org/research/publications/the-invisible-land (accessed 9 October 2020).

NHPAU (NATIONAL HOUSING AND PLANNING ADVICE UNIT) (2007), An NHPAU paper in response to the Government Green Paper 'Homes for the future: more affordable, more sustainable (report). National Housing and Planning Advice Unit, October 2007.

O'BRIENG, N. (2018), Green, pleasant and affordable: why we need a new approach to supply and demand to solve Britain's housing problem (report for UK Onward), June 2018, http://www.ukonward.com/wpcontent/uploads/2018/06/220618-Green-Pleasant.-Affordable-Web-ready.pdf (accessed 9 October 2020).

OFT (OFFICE OF FAIR TRADING) (2008), Homebuilding in the UK: a market study (report by Office of Fair Trading), September 2008,

http://webarchive.nationalarchives.gov.uk/20140402181400/http:/www.oft.gov.uk/shared oft/reports/comp policy/oft1020.pdf (accessed 9 October 2020).

OXFORD ECONOMICS (2016), Forecasting UK house prices and home ownership (A report for the Redfern Review into the decline of home ownership), Oxford Economics, November 2016.

RYAN-COLLINS, J., LLOYD, T., MACFARLANE, L. and MUELLBAUER, J. (2017), Rethinking the economics of land and housing, London, Zed Books.

SAYCE, S., CROSBY, N., GARSIDE, P., HARRIS, R. and PARSA, A. (2017), Viability and the planning system: the relationship between economic viability testing, land values and affordable housing, (Report prepared for London Boroughs of Barking and Dagenham, Brent, Camden, Croydon, Enfield, Greenwich, Islington, Lambeth, Merton, Newham, Southwark, Tower Hamlets and Waltham Forest), January 2017, http://taxpayersagainstpoverty.org.uk/files/Viability_and the Planning_System Research_January 20171.pdf (accessed 9 October 2020). 
SHELTER (2016), The case for greater land market transparency, Shelter Policy Library, November 2016, https://www.bl.uk/britishlibrary/ /media/bl/global/social-welfare/pdfs/non-secure/c/a/s/case-for-greaterland-market-transparency-briefing.pdf (accessed 9 October 2020).

SIRMANS S., L. MACDONALD, D. MACPHERSON and E. ZIETZ (2006), 'The value of housing characteristics: A metaanalysis', The Journal of Real Estate Finance and Economics, 33, 215-240.

SMITH, P. (2017), How much is my land worth? The Strategic Land Group, 13 March 2017, https://strategiclandgroup.co.uk/2017/03/13/the-essential-guide-how-much-is-my-site-worth/ (accessed 9 October 2020).

WARD, J., GREENWOOD, L. and MCLAREN, L. (2018), Residential development land, UK development Q3 2018, (Market in Minutes Savills Research), 25 October 2018, https://www.savills.co.uk/research articles/229130/267936-0/market-in-minutes--residential-developmentland-q3-2018 (accessed 9 October 2020).

WONG, G.K. (2002), 'A conceptual model of the household's housing decision-making process: The economic perspective', Review of Urban \& Regional Development Studies, 14, 217-234

WYATT, P. (2013), Valuation. $2^{\text {nd }}$ ed, Chichester, Wiley. 